\title{
Катетерне лікування тахіаритмій з використанням методики температурного картування і дискретних аплікацій у дітей віком до 5 років
}

\author{
Мешкова М. С. ${ }^{1}$, Доронін О. В. ${ }^{1,2}$, Ханенова В. А. ${ }^{1}$, Забашта Д. М. ${ }^{1}$, Руденко Н. М. ${ }^{1,2}$ \\ ${ }^{1}$ ДУ «Науково-практичний медичний центр дитячої кардіології та кардіохірургії МОЗ України» (Київ) \\ ${ }^{2}$ Національна медична академія післядипломної освіти імені П. Л. Шупика (Київ)
}

\begin{abstract}
Радіочастотні катетерні абляції (РЧА) для лікування тахіаритмій у дітей до 5 років застосовують не так часто, як у пацієнтів інших вікових категорій. Це зумовлено технічними складностями їх проведення і частим розвитком специфічних ускладнень, пов'язаних із розмірами тіла маленької дитини. У статті представлено власний досвід катетерного лікування тахіаритмій у дітей віком до 5 років із використанням методики температурного картування та дискретних аплікацій.

Проаналізовано 68 РЧА тахіаритмій у 56 дітей віком до 5 років, проведених із січня 2007 по грудень 2017 року. Безпосередня ефективність РЧА склала $88 \%$, після реоперацій - 96\%. Виникло 5 (7,3\%) ускладнень, 3 них 2 (2,9\%) потребували хірургічного втручання. Летальних випадків не було. Визначення в 2011 році чітких показань до проведення РЧА і впровадження «щадної» методики абляції в дітей віком до 5 років дозволило повністю уникнути ускладнень РЧА, але при цьому ефективність досягається відносно великою кількістю реоперацій (до 18\%) у старшому віці.

Таким чином, процедура РЧА у дітей перших років життя є достатньо ефективною та безпечною за умови дотримання певної методики.
\end{abstract}

Ключові слова: тахіаритмії, діти, катетерна абляція.

Протягом останнього десятиліття застосування РЧА дозволило значно покращити результати лікування тахіаритмій у дітей. Процедура РЧА має великі переваги порівняно з хронічною антиаритмічною терапією, але ії застосування у дітей раннього віку обмежено з огляду на специфічні ускладнення [1]. Тільки у восьми з 100000 дітей молодшого віку проводяться катетерні абляції, і з-поміж 1000 всіх РЧА саме дітям до 5 років проводиться всього одна [2].

Із 1 січня 1991 року в створеному в США Товариством дитячих електрофізіологів єдиному мультицентровому Педіатричному Реєстрі РЧА почала накопичуватись інформація про процедури РЧА, проведені пацієнтам віком до 21 року [3]. В результаті аналізу інформації з Реєстру в 2002 році виявилось, що ускладнення у дітей із вагою менше 15 кг виникають частіше. При цьому з часом загальна частота великих ускладнень зменшилася $34,2 \%$ до $3 \%$, а у дітей віком до 5 років збільшилася з 6\% до 9\%. Найбільш поширеними серйозними ускладненнями від РЧА, про які повідомлялося у згаданому вище Реєстрі, є повна АВ-блокада, утворення тромбів і перфорація стінки серця [4].

Дотепер немає загальновизнаних показань для проведення РЧА у дітей. Однак більшість авторів наголошує на тому, що мають бути дуже серйозні підстави для проведення РЧА дітям віком до 5 років та/або з вагою менше 15 кг [5-7]. Саме в цій віковій групі є вагомі технічні складності проведення РЧА і зареєстровано най- більшу кількість їі ускладнень [8]. Крім того, важливим фактором, що зумовлює обмежене використання РЧА у дітей перших років життя, є відносно позитивний прогноз при природному перебігу в них більшості тахіаритмій [9].

Враховуючи наявну інформацію, фахівці, що мають досвід проведення РЧА у дітей раннього віку, значною мірою самі визначають показання до цих процедур, виходячи з власного досвіду i, перш за все, ризику ускладнень, що найбільше залежить від віку та ваги дитини.

Мета дослідження - проаналізувати власний досвід катетерного лікування тахіаритмій у дітей віком до 5 років із використанням методики температурного картування та дискретних аплікацій.

Матеріали і методи дослідження. До досліджуваної групи ввійшли 56 дітей віком від 1 місяця до 5 років, яким у період із січня 2007 по грудень 2017 року в ДУ «НПМЦ ДКК» МОЗ України проведено 68 РЧА тахіаритмій. Середній вік на момент втручання становив $2,9 \pm 1,7$ років (від 1 місяця до 5 років 9 міс.), середня маса тіла - 17,3 $\pm 11,4$ кг (від 2,8 кг до 29 кг). Термін спостереження склав від 4 місяців до 10 років.

Серед процедур переважали абляції додаткових шляхів проведення. Реоперацій було 12 (17,9\%). Безпосередня ефективність РЧА склала $88,0 \%$, після реоперацій $-96,0 \%$. Сталося 5 (7,3\%) ускладнень, у тому числі 2 (2,9\%) - великі. Летальних випадків не було (табл. 1). 


\section{Таблиця 1}

Нозологічний розподіл РЧА і їх ускладнень

\begin{tabular}{lcccc} 
Процедури & Кількість & $\begin{array}{c}\text { Із них } \\
\text { реоперації }\end{array}$ & $\begin{array}{c}\text { Усклад- } \\
\text { нення }\end{array}$ & $\begin{array}{c}\text { Леталь- } \\
\text { ність }\end{array}$ \\
\hline $\begin{array}{l}\text { РЧА правосто- } \\
\text { роннього ДПШЗ }\end{array}$ & 33 & 5 & 2 & - \\
\hline $\begin{array}{l}\text { РЧА лівосто- } \\
\text { роннього ДПШЗ }\end{array}$ & 16 & 3 & 1 & - \\
\hline $\begin{array}{l}\text { РЧА передсерд- } \\
\text { ної тахікардії }\end{array}$ & 6 & 2 & 1 & - \\
\hline $\begin{array}{l}\text { РЧА шлуночкової } \\
\text { тахікардії }\end{array}$ & 5 & 2 & - & - \\
\hline $\begin{array}{l}\text { РЧА ріентрітахі- } \\
\text { кардії АВ-вузла }\end{array}$ & 8 & - & 1 & - \\
\hline Усього & $\mathbf{6 8 ~ ( 1 0 0 \% )}$ & $\mathbf{1 2}(\mathbf{1 7 , 9 \% )}$ & $\mathbf{5 ( 7 , 3 \% )}$ & -
\end{tabular}

Із 5 (7,3\%) ускладнень 3 (випіт у порожнині перикарда, гематома в місці судинного доступу та транзиторна АВ-блокада) проліковані консервативно, не потребували реабілітації та не знизили якість життя пацієнтів. Два $(2,9 \%)$ ускладнення (ятрогенна стійка повна АВ-блокада і псевдоаневризма стегнової артерії) потребували хірургічного втручання.

Із 2011 року в нашій клініці для дітей перших років життя визначено чіткі показання для проведення РЧА у дітей молодшого віку: персистуюча тахіаритмія зі зниженою фракцією викиду (ФВ) лівого шлуночка та пароксизмальна симптомна тахіаритмія у випадку їх резистентності на всіх етапах антиаритмічної терапії згідно з протоколом. 3 того ж часу для пацієнтів цієї вікової категорії впроваджено нову «щадну» методику РЧА з використанням температурного картування і нанесення дискретних аплікацій.

Для забезпечення процедур РЧА використовувалася загальна анестезія, переважно внутрішньовенна. У всіх дітей першого року життя та пацієнтів зі значно зниженою ФВ лівого шлуночка (нижче 40\%) РЧА було проведено в умовах ендотрахеального наркозу з ШВЛ. Радіочастотна абляція проводилась одним або двома незрошуваними катетерами 3 дистальним полюсом 4 мм та товщиною 6F (при масі тіла до 15 кг) або 7F. Параметри аплікацій було обмежено $53^{\circ} \mathrm{C}, 35 \mathrm{~W}, 40 \mathrm{c}$.

Після 2011 року в усіх дітей аплікації наносилися дискретно за температурою $\left(45^{\circ} \mathrm{C} \rightarrow 48^{\circ} \mathrm{C} \rightarrow 50^{\circ} \mathrm{C} \rightarrow 53^{\circ} \mathrm{C}\right) \mathrm{i}$ після температурного картування (thermo-mapping). При цьому в зоні інтересу спочатку наносились пробні аплікації з фіксованим обмеженням температури до $45^{\circ} \mathrm{C}$, що дозволяло оцінити їх ефективність і безпеку при зворотності можливих небажаних змін.

Результати та обговорення. Після впровадження в 2011 році чітких показань до РЧА у дітей молодшого віку, незважаючи на щорічне збільшення кількості дітей із тахіаритміями, які лікувались у нашій клініці, відсоток проведених у ранньому віці абляцій зменшився (табл. 2).

\section{Таблиця 2}

Результати РЧА у дітей віком до 5 років

\begin{tabular}{lcc} 
Результати & $\begin{array}{c}\text { 2007-2011 } \\
\text { роки }\end{array}$ & $\begin{array}{c}\text { 2012-2017 } \\
\text { роки }\end{array}$ \\
\hline Проведено РЧА & 27 & 41 \\
\hline $\begin{array}{l}\text { Проведено РЧА у дітей віком } \\
\text { до 3 років }\end{array}$ & $7(25,9 \%)$ & $8(19,5 \%)$ \\
\hline Кількість ускладнень & 5 & 0 \\
\hline Безпосередня успішність & $85 \%$ & $91 \%$ \\
\hline Кількість реоперацій & $4(14,8 \%)$ & $8(19,5 \%)$ \\
\hline $\begin{array}{l}\text { Середній вік на момент } \\
\text { первинної РЧА }\end{array}$ & $2,1 \pm 2,7$ року & $3,2 \pm 1,4$ року \\
\hline $\begin{array}{l}\text { Середня вага на момент } \\
\text { первинної РЧА }\end{array}$ & $12,3 \pm 9,4$ кг & $18,6 \pm 11,4$ кг
\end{tabular}

При порівнянні двох груп пацієнтів за 5 років - до і після впровадження показань до РЧА та «щадної» методики абляції - можна відзначити, що з 2012 року абляції проводилися старшим дітям із більшою масою тіла. При цьому, незважаючи на більшу кількість проведених за цей період РЧА у дітей молодше 5 років, ускладнень не було, а успішність процедур зросла з 85\% до 91\%.

Зростання безпосередньої успішності РЧА до $91 \%$ (за даними літератури - 82-89\%) ми пов'язуємо з тим, що після впровадження протоколу лікування, який більш ефективно запобігає виникненню тахікардій, нам вдається уникнути ургентних процедур і процедур у декомпенсованих пацієнтів.

Ми вважаємо, що новий протокол лікування і менш агресивні, чітко визначені показання до РЧА у дітей до 5 років дали нам можливість зменшити кількість абляцій, які проводяться в більш ранньому віці, коли ймовірність ускладнень найбільша. Це дозволило нам отримати незначний відсоток великих ускладнень при РЧА у дітей молодшого віку $-2,9 \%$ (за даними літератури 7-11\%).

Крім того, ускладнення РЧА у дітей молодшого віку пов'язані в основному з дією на тканини серця та оточуючих його структур енергії радіочастотного струму з агресивними параметрами, які рекомендовані в літературі для проведення РЧА. Проте при використанні рекомендованих параметрів зміни в тканинах зазвичай $€$ незворотними у зв'язку з процесом коагуляції білка. Запропонована нами «щадна» методика РЧА дозволяє переконатись у безпеці нанесення аплікації у вибраному місці, а при виявленні негативного впливу - негайно припинити ії без незворотних наслідків. Переваги такої методики підтверджуються відсутністю ускладнень при РЧА після ії впровадження.

Можна зазначити, що в другій групі пацієнтів наявний більший відсоток реоперацій, але всі вони були відстрочені та проведені в старшому віці. Ми вважаємо це виправданим на тлі відсутності ускладнень і досягнутої ефективності РЧА після реоперацій на рівні $96 \%$ (за даними літератури 92-95\%). 


\section{Висновки}

1. Процедура РЧА у дітей раннього віку є достатньо ефективною та безпечною.

2. РЧА у дітей до 5 років показана тільки при неефективності медикаментозного лікування, що дозволяє відстрочити інтервенцію.

3. «Щадна» методика РЧА дозволяє уникнути ускладнень у дітей раннього віку, проте результативність досягається за рахунок достатньо великої кількості реоперацій у старшому віці.

\section{Література}

1. Page RL, Joglar JA, Caldwell MA, Calkins H, Conti JB, Deal BJ, et al. 2015 ACC/AHA/HRS guideline for the management of adult patients with supraventricular tachycardia: a report of the American College of Cardiology/American Heart Association Task Force on Clinical Practice Guidelines and the Heart Rhythm Society. Circulation. 2016; 133:e506-e574. https://doi:10.1161/ CIR.0000000000000311

2. Backhoff D, Klehs S, Mbller MJ, Schneider H, Kriebel T, Paul T, et al. Radiofrequency catheter ablation of accessory atrioventricular pathways in infants and toddlers $\leq 15$ kg. Pediatr Cardiol. 2016;37(5):892-8. https://doi. org/10.1007/s00246-016-1365-z

3. Kugler JD, Danford DA, Deal BJ, Gillette PC, Perry JC, Silka MJ, et al. Radiofrequency catheter ablation for tachyarrhythmias in children and adolescents. The Pediatric Electrophysiology Society. N. Engl. J. Med. 1994;330(21):1481-7. https://doi.org/10.1056/ NEJM199405263302103
4. Kugler JD, Danford DA, Houston KA, Felix G; Pediatric Radiofrequency Ablation Registry of the Pediatric Radiofrequency Ablation Registry of the Pediatric Electrophysiology Society. Pediatric radiofrequency catheter ablation registry success, fluoroscopy time, and complication rate for supraventricular tachycardia: comparison of early and recent eras. J Cardiovasc Electrophysiol. 2002 Apr;13(4):336-41.

5. Greyling A, Ector J, Garweg C. Radiofrequency catheter ablation in infants and children. SA Heart. 2017;14:16-20. https://doi.org/10.24170/14-1-1864

6. An HS, Choi EY, Kwon BS, Kim GB, Bae EJ, Noh CI, et al. Radiofrequency catheter ablation for supraventricular tachycardia: a comparison study of children aged 0-4 and 5-9 years. Pacing Clin Electrophysiol. 2013;36(12):148894. https://doi.org/10.1111/pace. 12267

7. Radbill AE, Fish FA. Mapping and ablation of supraventricular tachycardia in pediatric and congenital heartdisease patients. Prog. Pediatr. Cardiol. 2013;35(1):6577. https://doi.org/10.1016/j.ppedcard.2012.11.009

8. Pilcher TA, Saarel EV. Anatomic Challenges In Pediatric Catheter Ablation. J Atr Fibrillation. 2014;7(2):1054. https://doi.org/10.4022/jafib.1054

9. Brugada J, Blom N, Sarquella-Brugada G, BlomstromLundqvist C, Deanfield J, Janousek J, et al. Pharmacological and non-pharmacological therapy for arrhythmias in the pediatric population: EHRA and AEPC-Arrhythmia Working Group joint consensus statement. Europace. 2013;15(9):1337-82. https://doi.org/10.1093/europace/ eut082

\title{
Catheter treatment of tachyarrhythmias in children under 5 years old using thermal mapping and discrete applications
}

\author{
Meshkova M. ${ }^{1}$, Doronin A. ${ }^{1,2}$, Khanenova V. ${ }^{1}$, Zabashta D. ${ }^{1}$, Rudenko N. ${ }^{1,2}$ \\ ${ }^{1}$ Ukrainian Children's Cardiac Center (Kyiv) \\ ${ }^{2}$ Ukrainian National Medical Postgraduate Academy (Kyiv)
}

Radiofrequency catheter ablation (RCA) for the treatment of tachyarrhythmias in children under the age 5 years is not used as often as in patients of other age groups. The RCA procedure has great advantages over chronic antiarrhythmic therapy, but its use in young children is limited due to specific complications.

The objective is to analyse our own experience in catheter treatment for tachyarrhythmias in children under the age of 5 years using the method of thermoal mapping and discrete applications.

Material and methods. The article presents the results of 68 RCA in 56 consecutive patients under the age of 5 years old, who underwent surgical interventions from 2007 to 2017. Ablations of accessory pathways were more frequent among the procedures. There were $12(17.9 \%)$ reoperations. The immediate efficacy of RFA was $88.0 \%$, after reoperations $-96.0 \% .5$ (7.3\%) complications were reported, of which $2(2.9 \%)$ were significant. There was no mortality.

RCA was carried out by one or two $6 \mathrm{~F}$ (with a body weight of up to $15 \mathrm{~kg}$ ) or 7F non-irrigated catheters with a 4-mm distal pole. The parameters of applications did not exceed $53^{\circ} \mathrm{C}, 35 \mathrm{~W}, 40 \mathrm{~s}$. After 2011, the applications were applied discretely at $\left(45^{\circ} \mathrm{C} \rightarrow 48^{\circ} \mathrm{C} \rightarrow 50^{\circ} \mathrm{C} \rightarrow 53^{\circ} \mathrm{C}\right)$ and after thermal mapping.

Results and discussion. After the introduction of clear indications to RCA in young children in 2011, despite an annual increase in the number of children with tachyarrhythmia treated in our clinic, the percentage of ablation performed at early age decreased.

Since 2012, ablations were performed in older children with a greater body weight. At the same time, despite the greater number of RCA in children younger than 5 years old during this period, there were no complications, and the success of 
procedures increased from $85 \%$ to $91 \%$.

We associate the growth of RCA direct success with the fact that we were able to avoid urgent procedures and procedures in decompensated patients.

A new treatment protocol and less aggressive, well-defined indications for RCA in children under the age 5 years have allowed us to reduce the number of ablation at earlier age when the probability of complications is greatest.

The 'gentle' RCA method allows us to make sure that the application in the selected place was safe, and in case of adverse effects - to immediately stop it without irreversible consequences. The advantages of this technique are confirmed by the absence of complications associated with RCA after the new method implementation.

Since 2012 we have had a higher percentage of reoperations (up to 18\%), but all of them were performed at older age. We consider this to be justified in the absence of complications and high efficacy of RCA.

Key words: tachyarrhythmias, children, catheter ablation. 